\title{
PENGARUH METODE PERMAINAN BERDASARKAN TEORI DIESNES TERHADAP MOTIVASI DAN HASIL BELAJAR SISWA KELAS IV SDN GRABAGAN SIDOARJO
}

\author{
Lucia Nanda Pramudya ${ }^{1)}$, Mohammad Edy Nurtamam ${ }^{2)}$ Andika Adinanda Siswoyo ${ }^{3)}$ \\ ${ }^{1,2,3)}$ Program Studi Pendidikan Guru Sekolah Dasar, Fakultas Ilmu Pendidikan, \\ Universitas Trunojoyo Madura \\ Email: luciapramudya30@gmail.com
}

\begin{abstract}
ABSTRAK. Penelitian ini bertujuan untuk mengetahui adakah perbedaan motivasi dan hasil belajar siswa yang menggunakan metode permainan berdasarkan teori diesnes di kelas IV SDN Grabagan Sidoarjo pada mata pelajaran matematika materi pecahan senilai. Penelitian kuantitatif jenis Quasi Experimental Design dengan desain Nonequivalent Control Group Desain. Teknik yang digunakan sampling jenuh, yaitu 56 sampel yang terdiri dari kelompok eksperimen dan kelompok kontrol. Teknik Pengumpulan data dalam penelitian ini yaitu angket dan tes. Teknik analisis data menggunakan uji t. Hasil penelitian yang diperoleh, 1) hasil analisis pada angket akhir motivasi belajar antara kelas eksperimen dan kotrol diperoleh $t_{\text {hitung }}=8,455>\mathrm{t}_{\text {tabel }}=2,006$. Berdasarkan hasil analisis Ho ditolak, sehingga menunjukkan ada perbedaan motivasi belajar matematika siswa kelas kontrol dan eksperimen yang menggunakan metode permainan berdasarkan teori diesnes di kelas IV; 2) hasil pada hasil posttest hasil belajar antara kelas eksperimen dan kontrol diperoleh $t_{\text {hitung }}=4,047>t_{\text {tabel }}=2,006$. Berdasakan hasil analisis Ho ditolak, sehingga menunjukkan ada perbedaan hasil belajar siswa antara kelas kotrol dan kelas eksperimen yang menggunakan metode permainan berdasarkan teori diesnes dikelas IV. Sehingga, dapat disimpulkan bahwa penerapan metode permainan berdasarkan teori diesnes memberikan pengaruh yang signifikan terhadap motivasi dan hasil belajar siswa kelas IV SDN Grabagan Sidoarjo.
\end{abstract}

Kata Kunci: Hasil Belajar, Motivasi Belajar, Metode Permainan Berdasarkan Teori Diesnes.

\section{Pendahuluan}

Pembelajaran merupakan suatu sistem. Pembelajaran tersebut ada suatu komponen utama diantara guru dan siswa. Namun demikian, komponen yang selama ini dianggap sangat mempengaruhi proses pendidikan adalah komponen guru. Guru merupakan ujung tombak yang berhubungan langsung dengan siswa sebagai subjek dan objek dalam pembelajaran (Sanjaya, 2006:13).

Keberhasilan suatu implementasi strategi pembelajaran akan tergantung pada kepiawean guru dalam mengemas suatu pembelajaran. Guru sebagai pengelola pembelajaran harus kreatif dan pandai dalam memilih metode atau strategi pembelajaran yang sesuai dengan karakteristik siswa, agar dapat meningkatkan motivasi dan hasil belajar siswa. Pada kegiatan pembelajaran guru juga harus mempunyai keterampilan dalam mengembangkan suatu pembelajaran agar mencapai suatu tujuan tertentu.

Pembelajaran matematika di sekolah dasar merupakan fondasi untuk mengembangkan pengetahuan matematika siswa. Runtukan \& Selpius (2014: 28) berpendapat bahwa pemusatan pengajaran matematika SD sering hanya pada keterampilan berhitung (penjumlahan, pengurangan, perkalian, pembagian bilangan bula, pecahan dan desimal) dan beranggapan 
bahwa jika anak telah menguasai berhitung ia telah menguasai semua kompetensi matematika. Pengertian matematika akan jelas bahwa matematika bukan hanya menekankan berhitung. Pengertian matematika yang tepat tidak dapat ditentukan secara pasti. Hal ini, karena cabang-cabang matematika semakin bertambah dan semakin berbaur satu dengan lainnya.

Pentingnya pembelajaran matematika perlu adanya perhatiaan guru untuk mengemas suatu pembelajaran. Suatu pembelajaran yang dikemas dengan metode yang inovatif dan menarik dapat meningkatkan motivasi siswa dalam pembelajaran, sehingga siswa semangat untuk belajar matematika. Selain itu, kepiawean guru dalam menciptakan kondisi dan situasi dalam kelas menjadi aktif, membuat pelajaran menjadi bermakna merupakan tugas seorang guru yang harus diperhatikan.

Berdasarkan hasil observasi dan wawancara pada hari Sabtu, tanggal 21 Oktober 2017 di kelas IV SDN Grabagan Sidoarjo. Hasil yang diperoleh dari observasi yang dilakukan bahwa $71,42 \%$ siswa atau sebanyak 40 dari 56 siswa menjawab tidak suka mata pelajaran matematika. Pembelajaran matematika adalah pelajaran paling sulit dan membuat mereka bosan saat pembelajaran berlangsung. Hal tersebut diperoleh dari hasil angket yang diberikan siswa pada saat observasi awal. Berdasarkan hasil wawancara yang dilakukan dengan guru kelas IV A. Kegiatan proses pembelajaran tersebut masih berpusatkan pada guru. Metode yang digunakan dalam pembelajaran adalah metode ceramah, tanyajawab dan penugasan. Motivasi siswa dalam pembelajaran masih termasuk golongan rendah, sehingga kurangnya keaktifan siswa dan pembelajaran kurang menarik dan kurang bermakna. Hal tersebut terbukti dengan hasil belajar yang didapatkan siswa masih rendah dan belum mencapai KKM yaitu 78.

Berdasarkan uraian diatas dapat disimpulkan bahwa metode yang digunakan guru kurang bervariasi. Seorang guru harus pandai memilih metode yang akan diajarkan sesuai dengan karakteristik siswa, sehingga nantinya pembelajaran akan bermakna dan siswa menjadi aktif. Salah satunya yaitu dengan menggunakan metode permainan. Pemilihan metode permainan dikarenakan metode sangat sesuai dengan karakteristik siswa yang suka bermain ketika belajar, sehingga dengan menggunakan metode tersebut bermain siswa lebih bermanfaat.

Metode permainan menurut Ningrum (2015:18) merupakan metode belajar dengan melakukan kegiatan yang menggembirakan yang dapat menunjang tercapainya tujuan instruksional matematika yang menyangkut aspek kognitif, psikomotor, atau efektif. Permainan yang mengandung nilai matematika dapat meningkatkan keterampilan, penanaman konsep, pemahaman, penemuan, memecahkan masalah, dan lain-lain. Metode permainan sama dengan metode-metode yang lain, yang 
memerlukan perumusan tujuan instruksional yang jelas, penilaian topik atau subtopik, perincian kegiatan belajar mengajar, dan lainlain.

Suatu tema atau topik yang disajikan dalam suatu pembelajaran matematika dapat berbentuk permainan. Hal ini membuat siswa menjadi senang, kesenangan yang tertanam pada diri siswa akan membentuk dorongan motivasi untuk mengikuti proses pembelajaran matematika, sehingga hasil belajar meningkat. Metode permainan ini membutuhkan sesuatu yang berbentuk konkret untuk menunjang pelajaran yang telah dilakukan. Adanya sesuatu yang berbentuk konkret ini siswa menjadi mudah untuk memahami suatu konsep tertentu. Metode permainan yang diterapkan sesuai dengan langkah-langkah teori yang dikemukakan oleh Diesnes. Metode permainan berdasarkan teori Diesnes ini diterapkan dapat membuat siswa lebih mudah untuk memahami materi.

Diesnes Resnick (dalam Irpan, 2012:109) mengungkapkan kunci dari pendekatan teori Diesnes dalam instruksi matematika adalah penggunaan benda-benda kongkrit dalam bentuk permainan dan permainan tersebut harus dilakukan secara hati-hati dan sesuai urutan pembelajaran. Konsep-konsep matematika akan berhasil jika dipelajari dalam tahap tertentu. Diesnes membagi tahap-tahap belajar menjadi 6 tahapan yaitu permainan bebas, permainan menggunakan aturan, permainan kesamaan sifat, permainan represensi, permainan dengan simbolis, dan permainan dengan formalisasi. Pada penerapan metode permainan berdasarkan teori diesnes, difokuskan pada tahap permainan bebas sampai dengan simbolisasi.

Berdasarkan latar belakang yang telah diuraikan, penelitian ini bertujuan: 1) Untuk mengetahui adanya perbedaan yang signifikan metode permainan berdasarkan teori diesnes terhadap motivasi belajar siswa kelas IV SDN Grabagan Sidoarjo. 2) Untuk mengetahui adanya perbedaan yang signifikan metode permainan berdasarkan teori diesnes terhadap hasil belajar siswa kelas IV SDN Grabagan Sidoarjo

\section{Metode Penelitian}

Penelitian ini menggunakan pendekatan kuantitatif jenis Quasi Experimental Design dengan desain Nonequivalent Control Group Desain. Dimana pada penelitian ini terdiri dari dua kelompok diantaranya kelompok eksperimen yaitu kelompok yang diberikan perlakuan dengan menggunakan metode permainan berdasarkan teori dieanes dan kelompok kontrol yaitu kelompok yang tidak diberikan perlakuan (pembelajaran konvesional). Penelitian dilaksanakan dikelas IV SDN Grabagan Sidoarjo dengan menggunakan teknik sampling jenuh, yaitu 56 sampel yang terdiri dari kelompok eksperimen dan kelompok kontrol.

Teknik Pengumpulan data dalam penelitian ini yaitu angket dan tes. Angket digunakan untuk mengetahui motivasi belajar 
siswa setelah mengikuti pembelajaran dengan menggunakan metode permainan berdasarkan teori diesnes. Sedangkan tes digunakan untuk mengetahui sejauh mana pengetahuan siswa setelah mengikuti pembelajaran dengan metode permainan berdasarkan teori diesnes. Instrumen tes hasil belajar siswa sebelum digunakan dalam penelitian dilakukan proses ujicoba soal kepada siswa lain yang telah memperoleh materi pecahan senilai untuk mendapatkan validitas, realibitas dan taraf kesukaran soal. Butir soal yang sesuai dengan indikator maka akan digunakan sebagai soal pretest dan posttets.

Angket motivasi siswa menggunkan angket ARCS Jhon Keller yaitu Attention, Relevance, Convidence, and Satisfaction. Angket motivasi ini menggunakan skala guttman yaitu setiap persyaratan dalam angket memiliki jawaban ya dan tidak. Setiap jawaban Ya diberikan nilai 1 untuk jawaban tidak diberikan skor 0 (Riduwan,2011:91). Setelah skor didapatkan dihitung nilai persentase rata-rata tiap pernyataan. Kemudian menentukan kategorinya dengan ketentuan persentase skor rata-rata dengan kategori sangat kuat, kuat, cukup, lemah dan sangat lemah. Lalu dianalisis menggunakan uji prasyarat yaitu uji normalitas dan uji homogenitas. Uji hipotesis dalam penelitian ini menggunakan uji komperatif dua sampel $t$ independent dan uji gain ternomalisasi.

Analisis data hasil belajar yang dilakukan dalam penelitian ini yaitu berupa pretest dan posttest yang dianalisis dengan menggunakan uji prasyarat yaitu uji normalitas dan uji homogenitas. Uji hipotesis dalam penelitian ini menggunakan uji komperatif dua sampel $\mathrm{t}$ independent dan uji gain ternomalisasi. Uji $\mathrm{t}$ independent digunakan untuk mengetahui perbedaan hasil belajar siswa antara menggunakan metode permainan berdasarkan teori diesnes dengan pembelajaran konvensional.

\section{Hasil dan Pembahasan}

Hasil uji coba tes hasil belajar yang telah diuji dengan uji validitas dengan rumus pearson product moment dari 40 soal diperoleh 26 soal valid dan 14 soal tidak valid. Uji reliabilitas diketahui sebesar 0,88008 dengan kategori reliabel sangat tinggi. Sedangkan uji taraf kesukaran soal dari 20 soal yang digunakan 3 soal mudah (15\%), 14 soal sedang (70\%), dan 3 soal sukar (15\%) (Arifin, 2012:271).

Hasil data angket motivasi yang diperoleh dari angket motivasi awal kelas kontrol dan eksperimen dapat diperoleh tiga kategori yaitu kuat, cukup, dan lemah. Untuk kelas eksperimen memperoleh skor rata-rata 10,821 dengan persentase $54,10 \%$ tergolong kategori cukupdan kelas kontrol memperoleh rata-rata 10,25 dengan persentase $51,25 \%$ kategori cukup. Hasil angket motivasi akhir kelas eksperimen dan kontrol memperoleh empat kategori yaitu sangat kuat, kuat, cukup dan lemah. Skor rata-rata yang diperoleh kelas eksperimen yaitu 15,9643 dengan persentase $79,82 \%$ dengan kategori kuat dan untuk kelas kontrol memperoleh skor rata-rata 
11,3214 dengan persentase $56,60 \%$ dengan kategori cukup. Jadi dapat disimpulkan bahwa motivasi siswa setelah diberikan perlakuan dengan metode permainan berdasarkan teori diesnes mendapatkan skor akhir untuk kelompok eksperimen memperoleh skor ratarata 15,9643 dengan persentase 79,82\% tergolong kategori kuat. Mengenai motivasi model ARCS menunjukkan bahwa komponen Attention memiliki rata-rata persentase 73,57\% dengan skor 20,6. Komponen Relevance memperoleh rata-rata persentase 83\% dengan skor 23,3. Komponen Confidence memperoleh rata-rata persentase 75\% dengan skor 21. Komponen Satisfaction memperoleh rata-rata persentase $88 \%$ dengan skor 24,6.

Uji normalitas bertujuan untuk mengetahui apakah data berdistribusi normal atau tidak. Data yang digunakan dalam uji normalitas adalah data angket awal dan akhir kelas eksperimen dan kelas kontrol. Hasil peroleh uji normalitas menunjukkan bahwa data angket awal kelas eksperimen berdistribusi normal, dengan hasil analisis $D_{\text {hitung }}=0,132<D_{\text {tabel }}=0,2290$. Data angket awal kelas kontrol berdistribusi normal, dengan hasil analisis $D_{\text {hitung }}=0,179<D_{\text {tabel }}=$ 0,2290 . Sedangkan data angket akhir kelas eksperimen berdistribusi normal, dengan hasil analisis $D_{\text {hitung }}=0,220<D_{\text {tabel }}=0,2290$. Data angket akhir kelas kontrol berdistribusi normal, dengan analisis $\mathrm{D}_{\text {hitung }}=0,182<$ $D_{\text {tabel }}=0,2290$. Kesimpulan dari hasil perhitungan uji normalitas menunjukkan bahwa data dari kelas eksperimen dan kontrol berdistribusi normal, sehingga untuk pengujian selanjutnya dapat menggunakan teknik statistik parametrik.

Pengujian selanjutnya adalah uji homogenitas. Uji homogenitas digunakan dengan tujuan untuk mengetahui ada atau tidaknya varians antara kelas eksperimen dan kontrol. Selanjutnya uji homogenitas ini menggunakan metode membandingkan antara varian terbesar dengan varians terkecil. Data yang digunakan dalam uji homogenitas angket awal menunjukkann tidak ada perbedaan varian antara kelas eksperimen dan kelas kontrol, dengan $\mathrm{F}_{\text {hitung }}=1,356<\mathrm{F}_{\text {tabel }}=1,9$. Sedangkan data angket akhir kelas eksperimen dan kelas kontrol menunjukkan tidak ada perbedaan varian antara kelas eksperimen dan kontrol, dengan $F_{\text {hitung }}=1,187$ $<\mathrm{F}_{\text {tabel }}=1$,9. Data hasil belajar siswa angket awal dan akhir dinyatakan berdistribusi normal dan bersifat homogen, sehingga memenuhi syarat dilakukan uji $\mathrm{t}$ (Siregar 2017:382).

Perhitungan uji hipotesis $\mathrm{t}$ independent yang bertujuan untuk mengetahui perbedaan antara kelas eksperimen dan kelas kontrol. Uji t yang digunakan menggunakan uji t dengan jenis polled. Pada hasil angket awal diperoleh $\mathrm{t}_{\text {hitung }}=-0,798<\mathrm{t}_{\text {tabel }}=2,0063$ maka $\mathrm{H}_{\mathrm{o}}$ diterima, artinya tidak ada perbedaan nilai angket akhir antara kelompok eksperimen dan kontrol yang membuktikan bahwa kemampuan awal sama antara dua sampel, sedangkan pada nilai angket akhir 
diperoleh $\mathrm{t}_{\text {hitung }}=8,455>\mathrm{t}_{\text {tabel }}=2,0063$ maka $\mathrm{H}_{\mathrm{a}}$ diterima, artinya ada perbedaan nilai angket awal antara kelas eksperimen dan kontrol, sehingga peneliti menyimpulkan bahwa ada pengaruh metode permainan berdasarkan teori diesnes terhadap hasil belajar siswa kelas IV SDN Grabagan Sidoarjo.

Pada penelitian ini perhitungan uji gain ternomalisasi bertujuan untuk mengetahui peningkatan nilai sebelum dan sesudah diberikan perlakuan. Hasil dari analisis diperoleh persentase $25 \%$ atau 7 dari 28 siswa mendapatkan peningkatan nilai dengan kategori tinggi. Sedangkan persentase $53,57 \%$ atau 15 dari 28 siswa dengan kategori sedang. Sedangkan persentase 14, 29\% atau 4 dari 28 siswa dengan kategori rendah, dan $7,14 \%$ atau 2 dari 28 siswa memperoleh kategori tidak terjadi penurunan. Kesimpulan bahwa semua siswa mengalami peningkatan tidak ada yang mengalami penurunan, hal tersebut terbukti bahwa metode permainan berdasarkan teori diesnes dapat meningkatkan hasil belajar siswa kelas IV SDN Grabagan Sidoarjo.

Mengenai motivasi model ARCS, perhatian (Attention) siswa dapat diperoleh dengan partisipasi aktif. Partisipasi aktif yaitu melalui permainan berdasarkan teori diesnes. Metode permainan merupakan salah satu metode yang dapat digunakan dalam menjelaskan materi matematika. Metode ini dapat meningkatkan motivasi siswa dengan cara ketika siswa terlihat tidak konsentrasi, bosan pada pelajaran yang dijelaskan oleh guru maka dialihkan dengan metode bermain dengan waktu tertentu sampai mereka kembali berkonsentrasi (Hamzah dan Muhlisrarini, 2014:281). Setiap siswa dalam kelompok belajar melakukan permainan dan melengkapi LKK yang telah diberikan. Selain itu dengan menggunakan berbagai metode dalam penyajian materi antara lain ceramah dan tanyajawab untuk menjelaskan materi.

Komponen relevansi (relevance) pada pembelajaran matematika ini dibuat secara menarik dan memadukan materi yang dipelajari dengan pengalaman langsung kepada siswa melalui permainan berdasarkan teori diesnes. Siswa akan lebih merasa tertarik dan senang dengan apa yang dipelejari dan pembelajaran yang telah dipelajari akan bermakna khususnya pembelajaran matematika. Perkembangan konsep matematika menurut Diesnes (dalam Pitadjeng, 2015:42) dapat dicapai melalui pola berkelanjutan, yang setiap seri dalam rangkaian kegiatan belajarnya berjalan dari yang konkret ke simbolik. Tahap belajar adalah interaksi yang direncanakan antara satu segmen struktur pengetahuan dan belajar aktif, yang dilakukan melalui media matematika yang didesain secara khusus, yang akan dimainkan siswa secara langsung.

Kompenen percaya diri (Confidence) dalam pembelajaran matematika ini dengan objek konkret yang dapat dikemas melalui permainan, sehingga membuat pembelajaran matematika lebih menarik dan mudah bagi 
siswa, sehingga termotivasi untuk mengikuti pembelajaran. Menurut Diesnes (dalam Pitadjeng, 2015:42) Objek-objek konkret dalam bentuk permainan mempunyai peranan sangat penting dalam pembelajaran matematika jika dimanipulasi dengan baik. Menurut Diesnes, permainan matematika sangat penting sebab operasi matematika dalam permainan tersebut menunjukkan aturan secara konkret dan lebih membimbing dan menajamkan pengertian matematika pada anak didik. Objek-objek konkret dalam bentuk permainan mempunyai peranan sangat penting dalam pembelajaran matematika jika dimanipulasi dengan baik sehingga membuat siswa senang.

Komponen yang terakhir daam motivasi siswa pada pembelajaran matematika ini yaitu kepuasan (satisfaction). Siswa merasa senang dan tertarik, dengan pembelajara yang menarik perhatian siswa. Hal ini pembelajaran matemtika dengan menerapkan metode permainan berdasarkan teori diesnes . Kepuasan siswa dapat munculketika siswa terlibat secara aktif dalam permainan yang diawali dengan permaianan bebas sampai permainan simbol yang menggunakan benda konkret, siswa berdiskusi kelompok. Selain itu siswa mendapatkan reward berupa applause dari guru dan temantemannya.

Hasil penelitian yang terkait dengan hasil belajar siswa dalam penelitian ini merupakan hasil belajar ranah kognitif yang diperoleh dari pretest dan posttest pada kelompok eksperimen (kelas IVB) dan kelompok kontrol (kelas IVA). Hasil pretest yang telah dilakukan diperoleh nilai rata-rata untuk kelompok eksperimen diperoleh 78,57\%, sedangkan kelompok kontrol diperoleh 78,57\%. Pada kelompok eksperimen dari 28 siswa diperoleh 6 siswa atau 21,42\% siswa yang tuntas atau mencapai nilai KKM. Sedangkan pada kelas kontrol dari 28 siswa diperoleh 6 siswa atau 21,42\% yang tuntas atau mencapai KKM.

Setelah dilakukan pretest pada kedua kelompok, kemudian diberikan pembelajaran berupa metode permainan berdasarkan teori diesnes untuk kelompok eksperimen dan pembelajaran konvensional untuk kelas kontrol. Setelah diberikan pembelajaran pada kedua kelompok selanjutnya diberikan nilai posttest. Hasil posttest kelompok eksperimen diperoleh dari 28 siswa terdapat 24 siswa atau $85,71 \%$ siswa yang tuntas atau mencapai KKM dan dari kelompok kontrol diperoleh dari 28 siswa terdapat 11 siswa atau $60,71 \%$ siswa yang tuntas atau mencapai KKM. Setelah dilakukan analisis nilai pretest dan posttest dilakukan uji prasyarat yaitu normalitas dan homogenitas.

Uji normalitas bertujuan untuk mengetahui apakah data berdistribusi normal atau tidak. Data yang digunakan dalam uji normalitas adalah data pretest dan posttest kelas eksperimen dan kelas kontrol. Hasil peroleh uji normalitas menunjukkan bahwa data pretetst kelas eksperimen berdistribusi normal, dengan hasil analisis $\mathrm{D}_{\text {hitung }}=0,164<$ 
$\mathrm{D}_{\text {tabel }}=0,2290$. Data pretest kelas kontrol berdistribusi normal, dengan hasil analisis $D_{\text {hitung }}=0,137<D_{\text {tabel }}=0,2290$. Sedangkan data posttest kelas eksperimen berdistribusi normal, dengan hasil analisis $D_{\text {hitung }}=0,154<$ $\mathrm{D}_{\text {tabel }}=0,2290$. Data posttest kelas kontrol berdistribusi normal, dengan analisis $\mathrm{D}_{\text {hitung }}=$ $0,35<\mathrm{D}_{\text {tabel }}=0,2290$. Kesimpulan dari hasil perhitungan uji normalitas menunjukkan bahwa data dari kelas eksperimen dan kontrol berdistribusi normal, sehingga untuk pengujian selanjutnya dapat menggunakan teknik statistik parametrik.

Pengujian selanjutnya adalah uji homogenitas. Uji homogenitas digunakan dengan tujuan untuk mengetahui ada atau tidaknya varians antara kelas eksperimen dan kontrol. Selanjutnya uji homogenitas ini menggunakan metode membandingkan antara varian terbesar dengan varians terkecil. Data yang digunakan dalam uji homogenitas pretest menunjukkann tidak ada perbedaan varian antara kelas eksperimen dan kelas kontrol, dengan $F_{\text {hitung }}=1,209<\mathrm{F}_{\text {tabel }}=1,9$. Sedangkan data posttest kelas eksperimen dan posttest kelas kontrol menunjukkan tidak ada perbedaan varian antara kelas eksperimen dan kontrol, dengan $F_{\text {hitung }}=1,350<\mathrm{F}_{\text {tabel }}=1,9$. Data hasil belajar siswa pretest dan posttest dinyatakan berdistribusi normal dan bersifat homogen, sehingga memenuhi syarat dilakukan uji t (Siregar 2017:382).

Perhitungan uji hipotesis $t$ independent yang bertujuan untuk mengetahui perbedaan antara kelas eksperimen dan kelas kontrol. Uji t yang digunakan menggunakan uji $\mathrm{t}$ dengan jenis polled. Pada hasil pretest diperoleh $\mathrm{t}_{\text {hitung }}=-0,640<\mathrm{t}_{\text {tabel }}=2,0063$ maka $\mathrm{H}_{\mathrm{o}}$ diterima, artinya tidak ada perbedaan nilai pretest antara kelompok eksperimen dan kontrol yang membuktikan bahwa kemampuan awal sama antara dua sampel, sedangkan pada nilai posttest diperoleh $\mathrm{t}_{\text {hitung }}$ $=4,0470>t_{\text {tabel }}=2,0063$ maka $H_{a}$ diterima, artinya ada perbedaan nilai posttest antara kelas eksperimen dan kontrol, sehingga peneliti menyimpulkan bahwa ada pengaruh metode permainan berdasarkan teori diesnes terhadap hasil belajar siswa kelas IV SDN Grabagan Sidoarjo.

Pada penelitian ini perhitungan uji gain ternomalisasi bertujuan untuk mengetahui peningkatan nilai sebelum dan sesudah diberikan perlakuan. Hasil dari analisis diperoleh persentase $64,28 \%$ atau 18 dari 28 siswa mendapatkan peningkatan nilai dengan kategori tinggi. Sedangkan persentase $35,71 \%$ atau 10 dari 28 siswa dengan kategori sedang. Kesimpulan bahwa semua siswa mengalami peningkatan tidak ada yang mengalami penurunan, hal tersebut terbukti bahwa metode permainan berdasarkan teori diesnes dapat meningkatkan hasil belajar siswa kelas IV SDN Grabagan Sidoarjo.

Berdasarkan hasil belajar kognif dalam penelitian ini, dapat disimpulkan bahwa hasil belajar siswa meningkat, dari hasil belajar meningkat, maka siswa dapat dikatakan telah melakukan proses belajar. Hal ini sesuai pendapat Hamzah (2014:20) Belajar 
harus memungkinkan perubahan terjadinya perubahan perilaku pada diri individu dalam aspek pengetahuan atau kognitif, nilai atau afektif, dan kerampilan, kemampuan, kompetensi (psikomotor).

Hasil observasi keterlaksanaan pembelajaran betujuan untuk mengetahui keterlaksanaan pembelajaran telah sesuai dengan RPP. Pada pertemuan memperoleh skor 90 dengan persentase $86,53 \%$ dengan kategori sangat baik. Pada pertemuan II diperoleh skor 92 dengan persentase 85,18\% dengan kategori sangat baik. Kesimpulannya bahwa hasil observasi keterlaksanaan pembelajaran dari pertemuan I ke pertemuan II mengalami peningkatan dan pembelajaran terlaksana.

Hasil observasi aktivitas siswa pada kelas eksperimen dan kelas kontrol. Kelas eksperimen pada pertemuan I diperoleh persentase $78 \%$ dengan katogori baik, dan pertemuan II diperoleh persentase $84 \%$ dengan katogori sangat baik. Hasil kelas kontrol pada pertemuan I diperoleh persentase 79\% dengan kategori baik dan pada pertemuan II diperoleh persentase $83 \%$ dengan kategori sangat baik.

\section{Kesimpulan}

Berdasarkan rumusan masalah, hasil dan pembahasan maka dapat disimpulkan bahwa: Hasil analisis uji $\mathrm{t}$ independent diperoleh nilai posttest hasil belajar antara siswa kelas eksperimen dan kontrol yaitu $t_{\text {hitung }}$ $=8,455>\mathrm{t}_{\text {tabel }}=2,0063$ maka $\mathrm{H}_{\mathrm{a}}$ diterima, artinya ada perbedaan nilai angket akhir antara kelas eksperimen dan kontrol, sehingga peneliti menyimpulkan bahwa ada pengaruh metode permainan berdasarkan teori diesnes terhadap hasil belajar siswa kelas IV SDN Grabagan Sidoarjo. Hasil analisis uji t independent diperoleh nilai posttest hasil belajar antara siswa kelas eksperimen dan kontrol yaitu $t_{\text {hitung }}=4,0470>t_{\text {tabel }}=2,0063$ maka $\mathrm{H}_{\mathrm{a}}$ diterima, artinya ada perbedaan nilai posttest antara kelas eksperimen dan kontrol, sehingga peneliti menyimpulkan bahwa ada pengaruh metode permainan berdasarkan teori diesnes terhadap hasil belajar siswa kelas IV SDN Grabagan Sidoarjo.

Beberapa saran yang dapat disampaikan dari hasil penelitian ini adalah sebagai berikut: (1) Guru sebaiknya dapat menjadikan metode permainan berdasarkan teori diesnes sebagai salah satu metode yang dapat digunakan untuk meningkatkan hasil belajar dan motivasi siswa khususnya pada pembelajaran matematika. Persiapan yang baik perlu diperhatikan dalam menggunakan metode permainan berdasarkan teori diesnes; (2) Guru dapat menggunakan metode permainan berdasarkan teori diesnes pada tingkat kelas lain, khususnya pada kelas rendah yang masih berada dalam masa bermain untuk meningkatkan motivasi siswa; (3) Jika Guru menggunakan metode permainan berdasarkan teori diesnes harus mengkaji materi, sebab tidak semua materi dapat disajikan dalam permainan; dan (4) 
peneliti lain diharapkan dapat mengemabangkan penelitian untuk teori diesnes yang berdasrkan metode lainnya yang sesuai.

\section{Pustaka}

Arifin, Zainal. 2012. Evaluasi Pembelajran. Bumi Siliwangi: PT RemajaRosadaya Hamzah, Ali dan Muhlisrarini. 2014. Perencanaan dan Strategi Pembelajaran Matematika. Jakarta: Rajawali Pers

Irpan, Samsul. 2012. “ Diesnes Multiple Embadiments And The Sequence Of Instruction". Mataram: Jurnal Beta. Vol. 5:2

Ningrum, Bealla Febrin Ravinda. 2015. Upaya Meningkatkan Hasil Belajar Matematika Menggunakan Metode Bermain Siswa Kelas III SDN 2 Pusporenggo KEC. Musuk KAB. Boyolali. Jawa Tengah: Jurnal Ilmiah Mitra Swara Ganesha. Vol. 2:1

Pitadjeng,M.Pd.2015. Pembelajaran Matematika Yang Menyenangkan. Yogyakarta: Graha Ilmu

Ridwan. 2011. Belajar Mudah Penelitian untuk Guru Karyawan dan Peneliti Pemula. Bandung: Alfabeta

Runtukahu, J dan Selpius Kandau.2014. Pembelajaran Matematika Dasar Bagi Anak Berkesulitan Belajar. Yogyakarta: Ar-Ruzz Media

Sanjaya, Wina. 2006. Strategi Pembelajaran Berorientasi Standar Proses Pendidikan. Jakarta: Kencana Prenadamedia Group

Siregar,Syofian.2017.Statistika Parametrik Untuk Penelitian Kuantitatif Dilengkapi dengan Perhitungan Manual dan SPPS Versi 17.Jakarta:BumiAksara 
